\title{
Torkildsen opererer
}

\author{
Arne Torkildsen (1899-1968) ble i 1937 ansatt som reservelege ved Nevrologisk avdeling ved Rikshospitalet. \\ Hans begivenhetsrike liv er tidligere omtalt i Tidsskriftet - oppstyret rundt den underkjente doktorgraden \\ i Oslo, en bejublet doktorgrad fra København, hans tid som professor i Kairo ... I Tidsskriftet nr. 5/1939 redegjør \\ han for et inngrep hos en ung kvinne med Ménières sykdom (Tidsskr Nor Lægeforen 1939; 59: 233-5).
}

\section{Nevrokirurgisk behandling av morbus Menièri.}

Av Arne Torkildsen, Oslo.

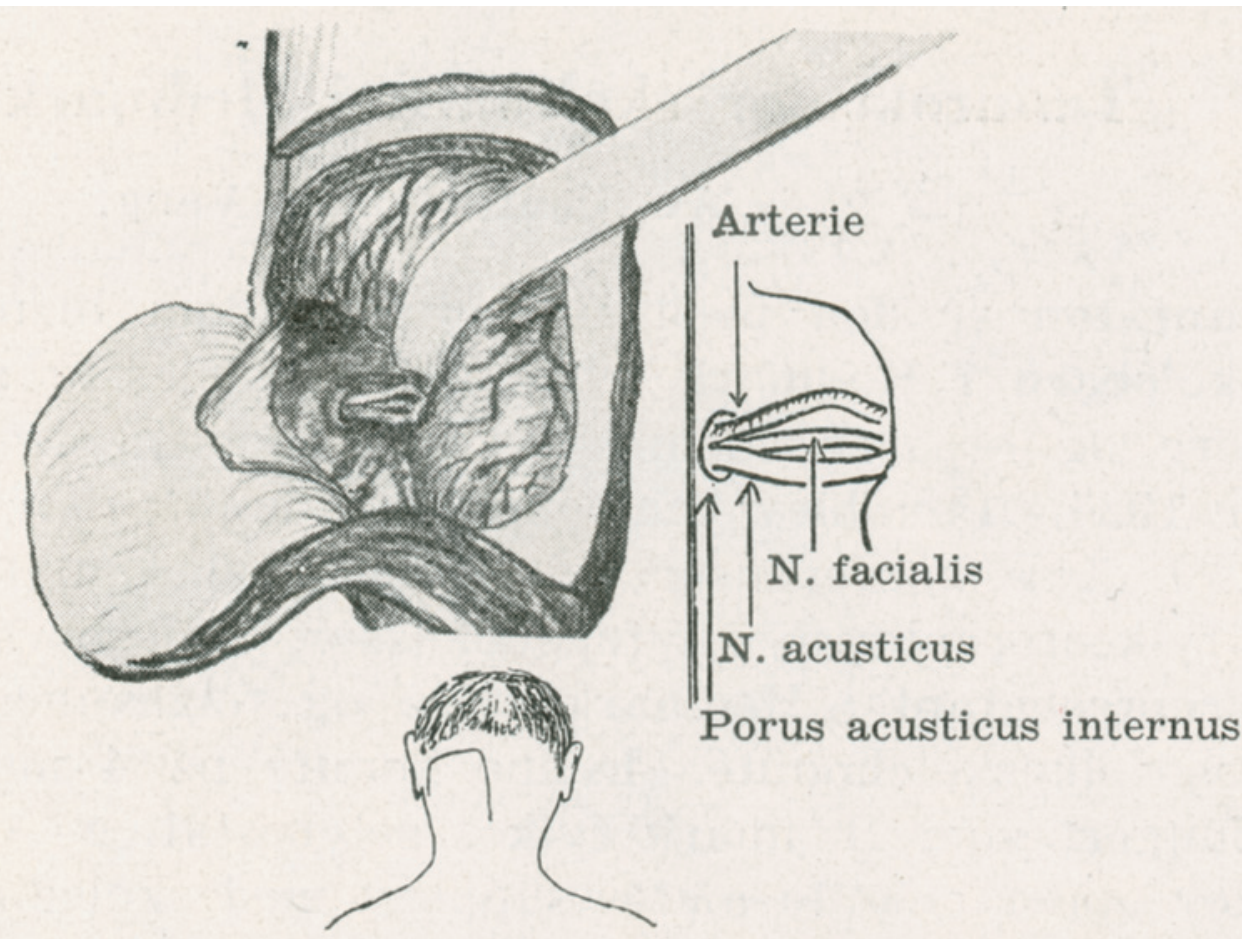

Fig. 1.

Patienten var en 28 år gammel kvinne som blev innlagt $\mathrm{i}$ Rikshospitalets nerveavdeling 16. juni 1938. Det fremgår av morens beretning at hun allerede omtrent 3 år gammel begynte å lide av svimmelhetsanfall idet hun nu og da kunde komme løpende og rope: jeg faller, jeg faller. Efter nogen tid ophørte disse anfall og hun var frisk til ca. 4 år før innleggelsen på avdelingen. Hun begynte da å bli plaget av vedvarende øresus på venstre side, og i de siste år hadde der vært tiltagende svimmelhetsanfall som etter hvert hadde gjort henne helt arbeidsudyktig.

Ved undersøkelse blev der funnet tvilsom nedsettelse av den sensible trigeminusfunksjon på venstre side. Enn videre var der svekket vestibularisfunksjon og døvhet på venstre side. For øvrig kunde intet sikkert abnormt påvises.

Operasjon: 21. juni 1938 utførte jeg i lokalanestesi en venstresidig suboksipital kraniotomi. Venstre cerebellarhemisfære blev retrahert i medial retning så det var mulig å få et overblikk over de anatomiske forhold i den cerebellopontine vinkel. Det viste sig da at sammen med n. acusticus og n. facialis løp en abnorm arterie av et kaliber vel så stort som n. facialis. Det kunde tydelig sees hvorledes arterien lå og pulserte og banket mot nervene. Arterien fulgte nervenes forløp fra hjernestammen inn i porus acusticus (fig. 1).

Pasienten befant sig under operasjonen i et av sine ofte timelange svimmelhetsanfall og berettet på spørsmål at hun hadde sin vanlige generende øresus.

Da det synes innlysende at den vaskulære malformasjonen gav en tilfredsstillende forklaring på lidelsens etiologi fjernet jeg arterien, og i samme øieblikk dette var tilendebragt fortalte patienten at nu var svimmelheten stoppet og øresusen betydelig bedret. Det kunde således neppe være tvil om at arterien var det irritament som utløste symptomkomplekset i dette tilfelle. Etter omhyggelig hemostase avsluttet jeg derfor operasjonen på dette stadium. 